\title{
Nutrition of the elderly: interactions with physical activity
}

Citation for published version (APA):

Westerterp, K. R. (2000). Nutrition of the elderly: interactions with physical activity. Aging Male, 3, 91-95. https://doi.org/10.3109/13685530009167829

Document status and date:

Published: 01/01/2000

DOI:

10.3109/13685530009167829

Document Version:

Publisher's PDF, also known as Version of record

Document license:

Taverne

Please check the document version of this publication:

- A submitted manuscript is the version of the article upon submission and before peer-review. There can be important differences between the submitted version and the official published version of record.

People interested in the research are advised to contact the author for the final version of the publication, or visit the DOI to the publisher's website.

- The final author version and the galley proof are versions of the publication after peer review.

- The final published version features the final layout of the paper including the volume, issue and page numbers.

Link to publication

\footnotetext{
General rights rights.

- You may freely distribute the URL identifying the publication in the public portal. please follow below link for the End User Agreement:

www.umlib.nl/taverne-license

Take down policy

If you believe that this document breaches copyright please contact us at:

repository@maastrichtuniversity.nl

providing details and we will investigate your claim.
}

Copyright and moral rights for the publications made accessible in the public portal are retained by the authors and/or other copyright owners and it is a condition of accessing publications that users recognise and abide by the legal requirements associated with these

- Users may download and print one copy of any publication from the public portal for the purpose of private study or research.

- You may not further distribute the material or use it for any profit-making activity or commercial gain

If the publication is distributed under the terms of Article $25 \mathrm{fa}$ of the Dutch Copyright Act, indicated by the "Taverne" license above, 


\section{Nutrition of the elderly: Interactions with physical activity}

\section{K. R. Westerterp}

To cite this article: K. R. Westerterp (2000) Nutrition of the elderly: Interactions with physical activity, The Aging Male, 3:2, 91-95, DOI: 10.3109/13685530009167829

To link to this article: https://doi.org/10.3109/13685530009167829

册 Published online: 05 Aug 2009.

Submit your article to this journal 준

Џ Article views: 38

Q View related articles $\sqsubset$ 


\title{
Nutrition of the elderly: interactions with physical activity
}

\author{
K. R. Westerterp \\ Department of Human Biology, Maastricht University, Maastricht, The Netherlands
}

Key words: DOUBLY LABELLED WATER, PHYSICAL ACTIVITY, BODY COMPOSITION, EXERCISE TRAINING

\begin{abstract}
Elderly subjects have a lower energy requirement compared to young adults as a result of lower physical activity and a lower basal metabolic rate. A lower energy intake in the elderly could lead to undesirable low intakes of essential nutrients. The reduction of the energy turnover is caused by, or a consequence of, a decrease in active cell mass. Thus, the effect of exercise training on habitual activity across age ranges, and age-related changes in body composition in relation to habitual activity level, are investigated here. The focus is on data on physical activity and body composition obtained with doubly labelled
\end{abstract}

\section{ENERGY REQUIREMENT AND AGE}

Energy requirements should be based on measurements of energy expenditure, not on estimates of energy intake'. Measurements of food intake have often been prone to errors, such as underrecording or undereating ${ }^{2}$. Since the doubly labelled water method has come into use for the measurement of energy expenditure in daily living conditions, it has become the gold standard for the assessment of energy requirement of all age groups, including the elderly. Here, data are presented on energy expenditure and body composition, as measured in Caucasian subjects tested in our laboratory since 1983. Subjects were excluded if they were $<20$ years of age, followed a specific diet for medical reasons (weight loss or weight gain), or followed a program of physical activity including athletic performance, pregnancy, lactation and disease (Table 1). water. The results suggest that exercise training does not affect energy requirement in the elderly and the age-related decrease in fat-free mass is not delayed in subjects with a relatively high habitual activity level. Beneficial effects of exercise training in the elderly are endurance, flexibility, range of motion and balance control, all contributing to a delay in the age-induced impairment of personal mobility. Energy intake will inevitably go down as a result of a reduction of the energy requirement. Thus, the nutrition of elderly subjects needs more attention with regard to the essential nutrients than the nutrition of younger adults.

There is a large individual variation in energy requirements, as shown in Figure 1. Differences between individuals can be twofold at all ages. On average, energy expenditure is higher in men than in women. Overall, average daily metabolic rate decreases with increasing age, and the decrease is similar for both genders. The average woman has an average daily metabolic rate of $11 \mathrm{MJ} /$ day at the age of 20 years and $5.5 \mathrm{MJ} /$ day at the age of 90 years. Values for the average man at corresponding ages are $14 \mathrm{MJ} /$ day and $7 \mathrm{MJ} /$ day, respectively. Thus, the average energy requirements of the very old are half of those of a young adult.

Individual variation in average daily metabolic rate and changes in average daily metabolic rate are a function of body size and physical activity. Body size, more specifically fat-free mass, is the

This paper was presented at the Second International Workshop on the Aging Male, Weimar, Germany, November 1999

Correspondence: Dr K. R. Westerterp, Department of Human Biology, Maastricht University, PO Box 616, 6200 MD Maastricht, The Netherlands

REVIEW 
Table 1 Subject characteristics and energy expenditure in different age and sex groups

\begin{tabular}{|c|c|c|c|c|c|c|c|c|c|c|c|}
\hline & \multirow[b]{2}{*}{$n$} & \multicolumn{2}{|c|}{ Height $(\mathrm{m})$} & \multicolumn{2}{|c|}{ Weight $(\mathrm{kg})$} & \multicolumn{2}{|c|}{$B M R(\mathrm{MJ} /$ day $)$} & \multicolumn{2}{|c|}{$\begin{array}{c}A D M R \\
\text { (MJ/day) }\end{array}$} & \multicolumn{2}{|c|}{$P A L$} \\
\hline & & mean & $S D$ & mean & $S D$ & mean & $S D$ & mean & $S D$ & mean & $S D$ \\
\hline \multicolumn{12}{|l|}{ Females } \\
\hline Aged $20-39$ years & 79 & 1.67 & 0.06 & 72 & 21 & 6.2 & 1.1 & 10.8 & 2.0 & 1.75 & 0.22 \\
\hline Aged $40-59$ years & 27 & 1.68 & 0.06 & 82 & 30 & 6.4 & 1.3 & 11.1 & 2.8 & 1.75 & 0.21 \\
\hline Aged $60-74$ years & 21 & 1.61 & 0.06 & 65 & 9 & 5.4 & 0.6 & 8.9 & 1.2 & 1.68 & 0.28 \\
\hline Aged $\geq 75$ years & 40 & 1.61 & 0.09 & 62 & 13 & 5.2 & 0.6 & 7.5 & 2.6 & 1.22 & 0.18 \\
\hline Total & 167 & & & & & & & & & & \\
\hline \multicolumn{12}{|l|}{ Males } \\
\hline Aged $20-39$ years & 99 & 1.80 & 0.06 & 85 & 23 & 7.9 & 1.3 & 14.0 & 4.8 & 1.79 & 0.23 \\
\hline Aged $40-59$ years & 61 & 1.77 & 0.06 & 90 & 19 & 7.7 & 1.1 & 14.4 & 2.7 & 1.90 & 0.28 \\
\hline Aged $60-74$ years & 37 & 1.74 & 0.07 & 80 & 13 & 7.0 & 1.1 & 11.1 & 1.9 & 1.60 & 0.25 \\
\hline Aged $\geq 75$ years & 37 & 1.70 & 0.05 & 72 & 9 & 6.4 & 0.9 & 9.2 & 1.9 & 1.40 & 0.26 \\
\hline Total & 234 & & & & & & & & & & \\
\hline
\end{tabular}

BMR, basal metabolic rate; ADMR, average daily metabolic rate; PAL, physical activity level (ADMR/BMR)
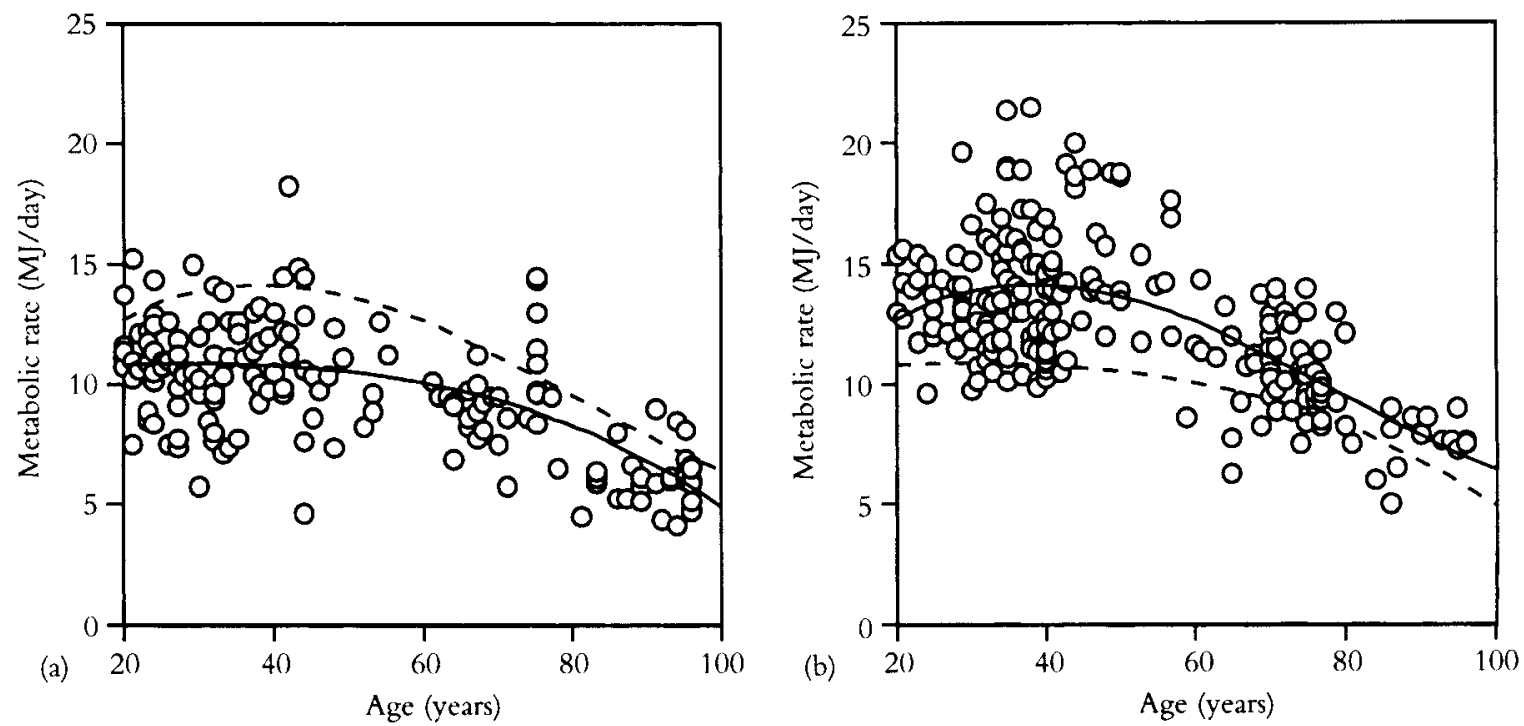

Figure 1 Average daily metabolic rate as a function of age for women (a) and men (b) with a fitted curve. The dotted line is the fitted curve of the other group

determinant of basal metabolic rate and basal metabolic rate is the main component of average daily metabolic rate. Activity-induced energy expenditure is the most variable component of average daily metabolic rate that can be strongly influenced by the behavior of a subject. Fat-free mass and physical activity are the explanatory variables for differences in average daily metabolic rate, and thus for differences in energy requirement, between individuals of the same age and for changes in average daily metabolic rate when individuals grow older.

Fat-free mass is a function of physical activity, energy balance and age. It is not easy to extricate the effects of the variables mentioned because of inter-relations. At a positive energy balance, the surplus is stored as fat mass and fat-free mass in a mass ratio of $75: 25$. At a negative energy balance, the deficit is recovered from fat mass and fat-free mass in the same ratio unless fat mass is below a 
critical value or intake is much lower than expenditure ${ }^{3}$. On average, subjects are in a positive energy balance up to middle age and fat-free mass shows a slight increase (Figure 2). Additionally, there is a general decline of fat-free mass with increasing age. The presentation of cross-sectional data shows a maximum for fat-free mass around the age of 40 years. Fat-free mass is higher in men than in women. Longitudinal data showed that the rate of decline speeds up in later years and is somewhat greater in the male 4 . The cross-sectional data in Figure 2 show the same phenomenon.

\section{ENERGY REQUIREMENT AND EXERCISE TRAINING}

There is a large interindividual variation in fat-free mass at any age, as presented for average daily metabolic rate (Figure 1). A basic question is whether fat-free mass, as a major determinant of the energy requirement of an individual, can be influenced. Is it possible by, for instance, exercise training to delay the age-related decline in fat-free mass? The effect of exercise training could be twofold: it could maintain fat-free mass and thus basal metabolic rate as the main component of average daily metabolic rate, and increase activityinduced energy expenditure as the most variable component of average daily metabolic rate. The overall effect would be maintenance, or even an increase, of average daily metabolic rate and thus of the energy requirement, reducing the risk of undesirable low intakes of essential nutrients.

Toth and colleagues ${ }^{5}$ reviewed studies that examined the effect of exercise on body composition in older individuals. They concluded that the effect of exercise was a function of exercise mode. In the selected intervention studies with a duration of at least 2 months, aerobic exercise reduced fat mass by $0.4-3.2 \mathrm{~kg}$, while resistance training reduced fat mass by $0.9-2.7 \mathrm{~kg}$. Resistance training also increased fat-free mass by $1.1-2.1 \mathrm{~kg}$, while aerobic training had no effect on fat-free mass. The loss of fat mass in response to aerobic training was related to the duration of the training, whereas the effects of resistance training on body composition were not related to the duration of the training. The next question then is whether elderly subjects can incorporate sufficient resistant exercise in the daily routine to delay significantly the progressive loss of muscle mass with aging.

There are a limited number of studies that examined the direct effect of exercise training on average daily metabolic rate (Table 2$)^{6}$. Exercise training had the largest effect on average daily metabolic rate in two studies with jogging as the exercise mode. The effect of indoor exercise was smaller but significant. However, there was one exception and this was the one study in the elderly. It was speculated that the level of exercise,
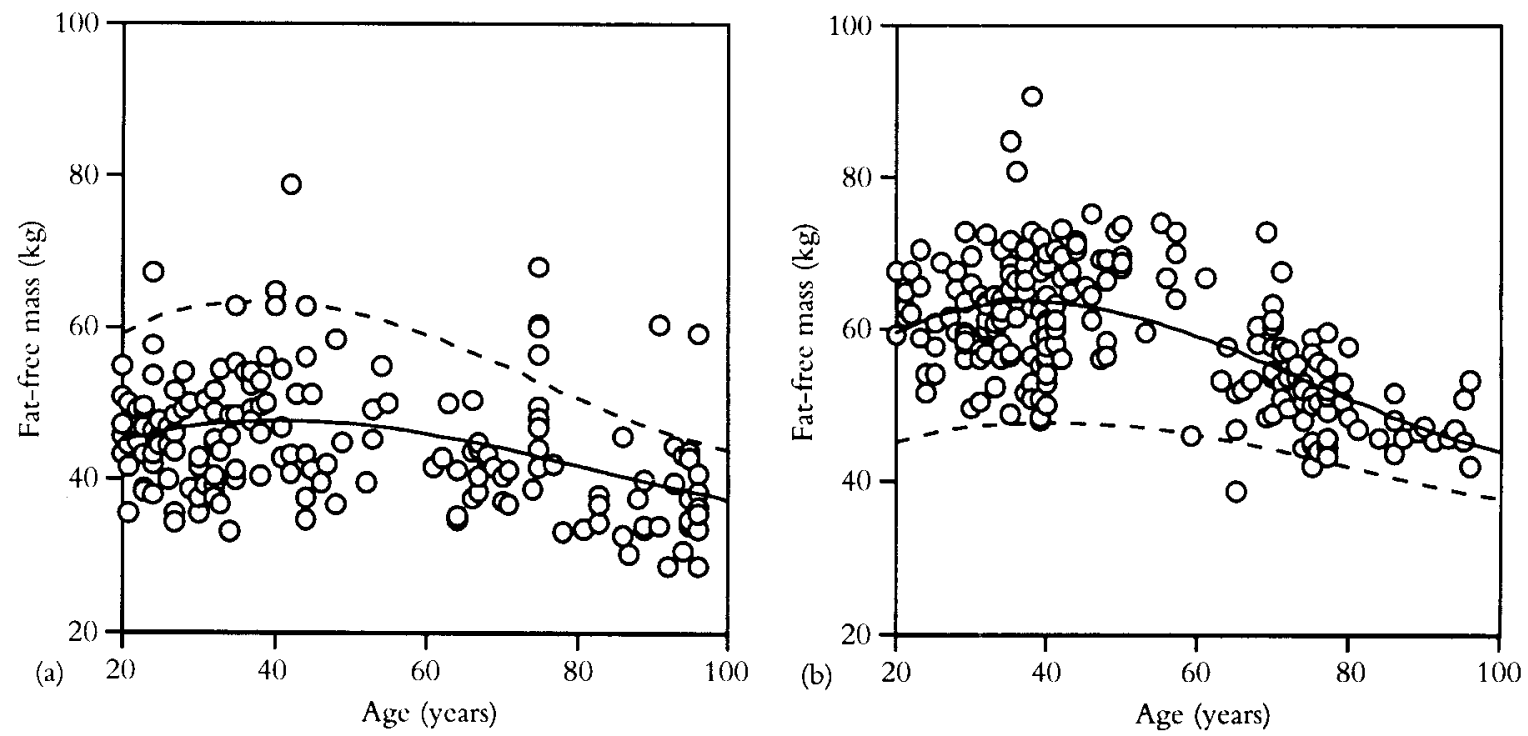

Figure 2 Fat-free mass as a function of age for women (a) and men (b) with a fitted curve. The dotted line is the fitted curve of the other group 
Table 2 Exercise intervention studies measuring the effect on average daily metabolic rate

\begin{tabular}{lccccc}
\hline & \multicolumn{2}{c}{ Subjects $(n)$} & & \\
\cline { 2 - 3 } Description of intervention & Female & Male & & Age (years) & $\Delta$ ADMR (\%) \\
\hline Jogging up to $1 \mathrm{~h} /$ day for 9 weeks & 2 & 3 & $24-33$ & $27 \pm 17$ \\
Five 1-h cycling sessions for 4 weeks & - & 10 & $10-11$ & $12 \pm 6$ \\
Three cycling sessions for 8 weeks & 5 & 6 & $56-78$ & 3 \\
Jogging up to 50 km/week for 40 weeks & 5 & 8 & $28-41$ & $21 \pm 9$ \\
Two weight-training sessions for 18 weeks & - & 12 & $23-41$ & $9 \pm 8$ \\
\hline
\end{tabular}

$\triangle \mathrm{ADMR}$, change in average daily metabolic rate

$3 \mathrm{~h} /$ week at $85 \%$ of $\mathrm{VO}_{2}-\max$, was too vigorous and therefore fatigued the elderly during the remainder of the day. However, Meijer and associates $^{7}$ showed the same phenomenon in elderly subjects using a training program of only moderate intensity. Exercise training does not influence spontaneous (non-training) activity except in the elderly. Elderly subjects show a compensatory effect and thus exercise training does not result in an increase in average daily metabolic rate and energy requirement.

\section{ENERGY REQUIREMENT AND HABITUAL ACTIVITY LEVEL}

The absence of an effect of exercise training on average daily metabolic rate in the elderly does not necessarily imply the absence of an effect of an active lifestyle on the age-related changes in energy requirement. Well-controlled exercise intervention studies are of short duration compared to the age-related change in average daily metabolic rate as depicted in Figure 1. We hypothesized that a relatively high habitual activity level delays the age-related changes in body composition and in energy requirement ${ }^{8}$. In order to compare activity levels across individuals, average daily metabolic rate, obtained using doubly labelled water, was adjusted for body size by expressing average daily metabolic rate as a multiple of basal metabolic rate (physical activity level $=$ average daily metabolic rate/basal metabolic rate). To allow comparisons of body composition between subjects, fat mass and fat-free mass were expressed as fat mass index and fat-free mass index, respectively.

$$
\text { Fat mass index }=\frac{\text { fat mass }}{\text { height }^{2}}
$$

$$
\text { Fat-free mass index }=\frac{\text { fat-free mass }}{\text { height }^{2}}
$$

where fat mass and fat-free mass are expressed in $\mathrm{kg}$ and height in $\mathrm{m}$.

In this way we corrected for differences in height, in analogy with the body mass index.

Body mass index $=$

fat-free mass index + fat mass index.

The characteristics of subjects included in the analysis are presented in Table 1.

Increasing age was associated with lower activity levels and lower fat-free mass. After controlling for age there was no longer any association between physical activity and fat-free mass. Elderly subjects with relatively high levels of physical activity were not different from those with low activity levels, as far as fat-free mass and fat mass were concerned. A higher habitual activity level does not delay the age-associated decline in fat-free mass and therefore basal metabolic rate, the main component of average daily metabolic rate. Of course, average daily metabolic rate, and thus the energy requirement, in subjects with a higher habitual activity level, is higher because of the higher physical activity level.

\section{DISCUSSION AND CONCLUSIONS}

The decline in energy requirement with age is a reflection of a decline in fat-free mass and a decline in physical activity. One hypothesis has been that maintaining high levels of physical activity with increasing age may delay the loss of muscle mass or fat-free mass. Conversely, subjects with a higher 
fat-free mass might find it easier to maintain a higher level of physical activity with increasing age. Therefore, in a cross-sectional sample, the more physically active subjects at a given age would also be expected to have a higher fat-free mass index. Surprisingly then, after controlling for age, there was no association between physical activity and fat-free mass. Apparently, there was no relation between habitual activity level and fat-free mass index, and elevated activity levels were not associated with a delayed loss of fat-free mass. Higher physical activity levels in subjects over 60 years were not associated with lower body fat, as had been shown previously for men aged $20-50$ years". We have to conclude that elderly subjects with relatively high levels of physical activity are not different from those with low activity levels, as far as fat-free mass and fat mass are concerned. In other words, body size and body fatness appear to be unrelated to physical activity levels in subjects over the age of 60 years.

An interesting phenomenon is the impact of exercise training on average daily metabolic rate and physical activity in elderly subjects. Goran and Poehlman ${ }^{10}$ demonstrated, in a well controlled study, that exercise training did not result in an increase in average daily metabolic rate. The imposed exercise training activity was compensated for by a corresponding decline in 'spontaneous' activity. In all past studies with younger subjects exercise intervention did not affect spontaneous physical activity, so that total energy expenditure showed a net increase. This was not the case in the elderly. The proposed explanation, that exercise fatigues elderly subjects and thus reduces spontaneous activity afterwards, resulting in the compensatory response even at moderate intensity training, seems too simplistic. Meijer and colleagues ${ }^{7}$ showed, with a tri-axial accelerometer for movement registration, that elderly subjects anticipate the advent of exercise training by lowering their physical activity even before the exercise training sessions.

Finally, energy intake will inevitably go down as a result of a reduction of the energy requirement. Knowing that the intake of most nutrients depends on total energy intake, this lower energy intake in the elderly could lead to undesirable low intakes of protein, minerals and vitamins. Thus, the nutrition of elderly subjects needs more attention with regard to the essential nutrients than the nutrition of younger adults.

\section{References}

1. Food and Agriculture Organization, World Health Organization and United Nations University. Energy and Protein Requirements. WHO Technical Report Series 724. Geneva: WHO, 1985

2. Goris AHC, Westerterp KR. Underreporting of habitual food intake is explained by undereating in highly motivated lean women. J Nutr 1999;129: 878-82

3. Westerterp KR, Donkers, Fredrix EWHM, Boekhoudt P. Energy intake, physical activity and body weight: a simulation model. Br J Nutr 1995; 73:337-47

4. Forbes GB, Reina JC. Adult lean body mass declines with age: some longitudinal observations. Metabolism 1970;19:653-63

5. Toth MT, Beckett T, Poehlman ET. Physical activity and the progressive change in body compo- sition with aging: current evidence and research issues. Med Sci Sports Exerc 1999;31:S590-6

6. Westerterp KR. Alterations in energy balance with exercise. Am J Clin Nutr 1998;68(Suppl):970S-4S

7. Meijer EP, Westerterp KR, Verstappen FTJ. Effect of exercise training on total daily physical activity in elderly humans. Eur J Appl Physiol 1999;80:16-21

8. Westerterp KR, Meijer EP. Physical activity and parameters of aging: a physiological perspective. $J$ Gerontol 2000;in press

9. Westerterp KR, Meijer GAL, Kester ADM, Wouters $\mathrm{L}$, Hoor ten F. Fat-free mass as a function of fat mass and habitual activity level. Int $J$ Sports Med 1992;13:163-6

10. Goran MI, Poehlman ET. Endurance training does not enhance total energy expenditure in healthy elderly persons. Am J Physiol 1992;263:E950-7 